\title{
Back-shoring vs near-shoring: a comparative exploratory study in the footwear industry
}

\author{
Fernando Merino $^{1} \cdot$ Cristina Di Stefano $^{2} \cdot$ Luciano Fratocchi $^{2}$ (D) \\ Received: 26 May 2020 / Revised: 8 November 2020 / Accepted: 24 November 2020 / Published online: 6 January 2021 \\ (C) The Author(s), under exclusive licence to Springer Science+Business Media, LLC part of Springer Nature 2021
}

\begin{abstract}
After decades of off-shoring strategies, companies are often critically re-evaluating their earlier location decisions; in doing so, sometimes they implement the so-called relocation of second degree. Among them, back-shoring (i.e., relocation to the home country) and near-shoring (relocation to the home region) are two of the alternatives attracting growing interest from scholars. This paper aims to shed new light on the variables influencing the choice made between these two alternatives. As requested in the extant literature, a contingency approach is adopted, focusing attention on the footwear industry. Given the exploratory nature of the paper, evidence from 41 back-shoring and near-shoring strategies are analysed, comparing data from Spanish and Italian companies. Collected data are adapted to test hypotheses concerning three sets of variables: firms' characteristics, motivations for the second degree relocation and its barriers. Collected data show that firm's size directly influences the chosen alternative since larger companies prefer to near-shore instead of back-shore. When considering motivations, while the "made in" effect does not influence the firm's choice, availability of skilled contractors and/or government aids induces companies to relocate to the home country instead of the home region. Finally, companies fearing encountering barriers, in terms of skilled contractors' availability and/or (re-)development of internal manufacturing competences, will prefer the back-shoring rather than the near-shoring option. The study is focused on two countries (Spain and Italy) where the manufacturing sector (and the footwear industry within it) is still relevant to the local economy. Findings cannot be generalized to countries/industries where the local industry has been totally dismantled, without a previous in-depth analysis. The findings obtained offer managers useful insights on the elements that should be carefully evaluated when considering back- and near-shore alternatives. Additionally, valuable insights are provided for policy makers that plan to design industrial policies supporting back-reshoring policy initiatives. To the best of our knowledge, this is the first paper in the extant literature addressing variables influencing the choice between back- and near-shoring alternatives.
\end{abstract}

Keywords Reshoring $\cdot$ Back-shoring $\cdot$ Near-shoring $\cdot$ Footwear $\cdot$ Manufacturing $\cdot$ Spain $\cdot$ Italy

\section{Introduction}

Western manufacturing companies have been implementing production off-shoring strategies - often coupled with out-

Luciano Fratocchi

luciano.fratocchi@univaq.it

Fernando Merino

fmerino@um.es

Cristina Di Stefano

cristina.distefano@univaq.it

1 Department of Applied Economics, University of Murcia, Murcia, Spain

2 Department of Industrial and Information Engineering and Economics, University of L'Aquila, L'Aquila, Italy sourcing ones - at least since the 1980s. Such a location decision has often been considered as the only strategic alternative to remain competitive in the global market, due to the increasing competitiveness of emergent and less developed countries (e.g., Asia and Latin America) (Ferdows 1997). However, several disturbances have affected firms' supply chains therefore companies have had to develop strategies to cope with them (Huq et al. 2016). As a consequence, at least in the last decade, manufacturing companies have been increasingly reviewing their earlier location strategies, often redesigning their production footprint at the worldwide level (Ferdows 2018). More specifically, they have implemented one or more of the so-called "relocation of second degree" (Barbieri et al. 2019) or "reshoring" strategies (Foerstl et al. 2016; Fratocchi et al. 2014). This means that they decided to relocate production activities according to one of the following three alternatives (Fratocchi et al. 2014): 
i. to relocate production activities to the home country: this strategic option has been addressed, among others, as back-reshoring (Fratocchi et al. 2014) or back-shoring (Foerstl et al. 2016);

ii. to relocate manufacturing activities to a country located in the firm's home region: this alternative has generally been referred to as near-reshoring (Fratocchi et al. 2014) or near-shoring (Foerstl et al. 2016);

iii. relocation to a region far away from the home one: this strategy has been referred to as further off-shoring (Fratocchi et al. 2014).

While the further off-shoring alternative is consistent with the traditional linear conceptualization of the internationalization process (Johanson and Vahlne 1977, 1990), the other two options are based on the concept of "nonlinear internationalization", i.e., an internationalization path "characterized by substantial increases and decreases in international activity" (Vissak 2010, p. 560). Therefore, they deserve specific attention by scholars (Fratocchi et al. 2014, 2015). However, the terms back-reshoring and near-reshoring suggested by Fratocchi et al. (2014) are not very diffused in the extant reshoring literature. Therefore, in this paper we prefer to refer to the more usually adopted terms of near-shoring and backshoring adopted by Foerstl et al. (2016). Moreover, we consider the neighbourhood of the firms' home countries (East Europe, North Africa and Middle East) as being the region where relocations can be considered as near-shoring, keeping the rest of the world for further off-shoring cases). In this way, we follow Fratocchi et al.'s (2014) suggestion to adopt Ohmae's (1985) perspective when defining the near-shoring concept.

Although the back-shoring phenomenon has gained increasing attention among scholars in recent years (Barbieri et al. 2018; Stentoft et al. 2016c; Wiesmann et al. 2017), studies on near-shoring are still scarce (Slepniov et al. 2013). Moreover, the academic literature rarely compares the two phenomena in order to understand why companies prefer to implement one instead of another (Di Mauro et al. 2018). At the same time, Yu and Kim (2018) explicitly requested future research should define criteria to compare nearand back-shoring alternatives. This request assumes a growing relevance when you consider Piatanesi and Arauzo-Carod (2019) who pointed out that near-shoring "is still a limited phenomenon $[. .$.$] but it is reasonable to assume [\ldots$ it ...] will relatively soon increase significantly". They justify their statement pointing out that the near-shoring alternative combines the advantages of both off-shoring and back-shoring strategies (Piatanesi and Arauzo-Carod 2019, pp. 13-14).

Finally, back- and near-shoring have attracted further attention by scholars and policy makers after the emergence of the Covid-19 pandemic since they were recognized as two of the four alternative trajectories of international production (UNCTAD 2020). More specifically, the two strategies refer to the scenario of GVCs' (Global Value Chains) reconfiguration - which implies the concentration of activities in either one or a few countries belonging to the same region (Enderwick and Buckley 2020; Gereffi 2020; Strange 2020); while diversification and replication belong to that of GVCs' resiliency - where the production activities remain fragmented across countries and regions. Independently of the scenario, scholars recognize industrial policy will have a critical role in the post-pandemic era (Betti and Hong 2020; De Meyer 2020; Gereffi 2020). In this respect, it is worth noting that several countries have already implemented (e.g., France, Japan, South Korea), or are at least discussing the opportunity to enact (e.g., Australia; Italy), industrial policies aimed at support back-shoring strategies and even near-shoring ones (as in the case of the Japanese government).

This paper aims to shed new light on the relevance of some variables to influence the firm's choice between back- and near-shoring strategies. In order to reach such an objective, we depart from the extant literature on relocation of second degree to propose some hypotheses that may determine the option between returning home (back-shoring) or to nearby countries (near-shoring). In this respect, it must be taken into account that to conduct this type of analysis considering the whole manufacturing sector faces the risk that specific factors (either referring to the external environment - such as changes in the technology and trade barriers - or to the single company - such as the production capabilities and available financial resources) may differ among industries. Therefore, we believe analyses should be implemented at the industry level. Consequently, we choose to focus on the footwear industry which has been significantly characterized by off-shoring strategies in the last few decades (Rashid and Barnes 2017). In this respect, during the $2010 \mathrm{~s}$, over $90 \%$ of apparel and footwear companies in the US moved their production activities overseas (Yu and Kim 2018). However, in the same industry, some evidence of back-shoring strategies has emerged. For instance, Martínez-Mora and Merino (2014) showed that 10 out of the 15 major Spanish companies located in the Alicante industrial district in the previous five years decided to back-shore, independently of their product lines (e.g., dress shoes vs. sport ones) and market targets (mid-range vs. midhigh and high ones). At the same time, similar evidence has also been pointed out in Italy (Baraldi et al. 2018; Di Mauro et al. 2018) and Portugal (Fratocchi and Costa e Silva 2018). However, to the best of our knowledge, there is no research comparing back-shoring and near-shoring strategies in this (and even other) industry.

In order to reach the research aim, we will try to explain the importance that three main issues have on the choice between back- and near-shoring strategies. Basically, they are:

i) characteristics of the companies implementing the relocation of second degree: given the focus on the 
footwear industry, the comparison will be conducted in terms of firm's size;

ii) motivations inducing companies to relocate;

iii) barriers to the implementation of the relocation decision.

Our analysis will be based on the features of 41 back- and near-shoring decisions implemented by 25 Italian and Spanish companies operating in the footwear industry.

The rest of the paper is structured as follows: the next section will present a structured literature review of both the back- and near-shoring phenomena that will support the research hypotheses. More specifically, 146 Scopus indexed journal articles published up to August 2020 will be analysed, in order to define the state-of-the-art. After this, the characteristics of the footwear industry will be summarized, with a specific focus on the Italian and Spanish contexts. Section 4 contains a description of the sampled back- and near-shoring decisions while in the following section quantitative findings are presented and discussed. Main conclusions and implications for scholars, managers and policy makers will be summarized in the last section.

\section{Theoretical background and hypothesis development}

\subsection{The extant literature on back-shoring and near- shoring decisions}

In order to define the theoretical background of the backshoring and near-shoring phenomenon, an exhaustive review of the academic literature has been developed. We searched for all the published papers in the Scopus database (since its coverage is wider than others such as Econlit or WoS) looking for journal articles published in English until August 2020 and related to the topics of near-shoring and back-shoring (see Table 5 in Appendix for details of the literature review). The methodology adopted to select the 153 journal articles useful to sustain the research questions is described in Appendix A.

Selected articles on back-shoring have been published since 2007 while those regarding near-shoring only since 2012. As already noted for back-shoring articles (Barbieri et al. 2019), also the near-shoring ones were mainly published in operation and supply chain management journals.

As a result of the exhaustive review of the literature, it can be stated that only two articles compare the near-shoring alternative with back-shoring and further off-shoring. More specifically, while Ancarani et al. (2015) consider back- and nearshoring as "similar strategies", Zhang and Huang (2012) found near-shoring should be preferred to the further offshoring alternative when the company aims to improve its market responsiveness; otherwise the relocation to an even far away host country should be preferred when the company goal is cost efficiency. Therefore, no author has specifically addressed which issues induce companies to prefer either the back- or near-shoring alternative. In order to fill this gap, we checked the sampled literature to select documents addressing the decision-making process characterizing such relocation strategies. In doing so we found six journal articles, namely: Bals et al. 2016; Benstead et al. 2017; Boffelli et al. 2018, 2020; Boffelli and Johansson 2020; Gray et al. 2017). Among them, Boffelli and Johansson (2020) offer the most comprehensive and detailed framework of the off-shoring and reshoring processes; more specifically both processes are articulated in three phases - decision-making, implementation and outcomes - which are influenced by some contingencies. For the aims of our contribution, attention was specifically focused on the decision-making phase of the reshoring strategy. According to Boffelli and Johansson (2020), during this phase companies should specifically evaluate two "factors", motivations/drivers (hereafter referred to just as motivations) and barriers. Therefore, we assume that - in order to investigate why companies prefer either the back- or near-shoring alternative - three main elements should be investigated: contingencies, motivations and barriers. Consequently, we checked the sampled literature to identify specific items referring to such elements in order to develop research hypotheses to be tested.

As far as contingencies are concerned, firm's size and industry are among the most cited (e.g., Bals et al. 2016; Benstead et al. 2017, suggest size and industry are among the most relevant). Since we decide to test our hypotheses on a sample of companies belonging to the same industry (footwear), to eliminate a potential source of bias, our attention was focused on the company size issue, which was extensively investigated by reshoring scholars, at least those studying relocation to the home country. For instance articles based on German data (Dachs et al. 2019a; Kinkel 2014; Kinkel and Maloca 2009) show large companies are more likely to implement the relocation strategy under investigation. The higher propensity for large firms to back-shore, when compared to small and medium-sized enterprises (SMEs), has also been found in Scandinavian firms (Heikkilä et al. 2018a, b; Johansson and Olhager 2018a). However, Canham and Hamilton (2013) showed New Zealand SMEs have a higher propensity to back-shore when compared to larger firms. Finally, other scholars (Fel and Griette 2017; Fratocchi et al. 2016) found back-shoring is almost equally distributed among the two classes of firm's size. Finally, of specific note is the Ancarani et al. (2015) finding regarding the off-shoring duration, i.e., the time that elapses between the decision to off-shore and the one to backshore. In this respect, they found SMEs generally relocate production to the home country after a shorter time; this could be explained by the lower amount of resources such 
companies own. In other words, given the resources' scarcity when encountering problems abroad, SMEs are more likely to back-shore than to remain off-shore and try to cope with the foreign environment. In the near-shoring literature, the only journal article investigating this issue (Fel and Griette 2017) did not find any difference between companies that backshored and those that near-shored.

Concerning the motivations issue, it has been pointed out that they are the most investigated in the extant back-shoring literature (Barbieri et al. 2018). Therefore, scholars have proposed dozens of variables (e.g., Barbieri et al. 2018; Srai and Ané 2016) showing they are related to both cost issues (e.g., logistics costs and reduction of labour cost gap between host and home country) and to the firm's effectiveness (e.g., "made in effect" and higher responsiveness to customer needs). Based on such evidence some authors proposed frameworks aimed at classifying the large amount of motivations; among them, Fratocchi et al. (2016) developed a theoretically based model which takes into account the motivation origin (divided between those belonging to the company and those belonging to the external environment) and nature (drivers oriented to cost efficiency vs. those regarding value effectiveness). Also for near-shoring, scholars proposed several drivers (e.g., Fel and Griette 2017), ranging from the cost-related ones (e.g., labour and coordination costs) to the value-related ones (e.g., poor product quality and lead time). Moreover, Johnson (2012) referred to intellectual property and regulatory issues. To sum up, near-shoring scholars seem to conclude that motivations inducing the relocation of production activities to the home region are no different from those characterizing the back-shoring phenomenon. Of special note is the role of industrial policies as a driver of back- and near-shoring strategies. Before the Covid-19 emergence, scholars generally maintained that industrial policies are rarely the drivers of back-shoring strategies (Srai and Ané 2016; Zhai et al. 2016). At the same time, Fratocchi et al. (2016) found evidence that only 28 out of 377 relocations were boosted by (host country) governmental incentives and only three of those were encouraged by Customs Duty for re-import. However, following Covid-19, scholars (Gereffi 2020) and policy makers (Betti and Hong 2020; De Meyer 2020; UNCTAD 2020) stated industrial policy will heavily influence the evolution of GVCs, either according to the reconfiguration scenario or the resiliency one. Therefore, it would be interesting to know whether industrial policies implemented in the home country may induce companies to prefer backshoring, instead of the near-shoring alternative, in order to provide a reference point to compare results in future research.

Finally, the barrier issue has been investigated only in the last three years. Among scholars investigating the backshoring alternative, Engström et al. (2018a, b) developed a list of 24 barriers, ranging from home country labour market legislation to the firm's internal competency. Regarding the latter, Nujen et al. $(2018,2019)$ specifically refer to production activities. At the same time, Chen and $\mathrm{Hu}$ (2017) and Boffelli et al. $(2018,2020)$ point out that the unavailability of skilled suppliers in the home country emerges as a critical barrier Finally, no articles were found that addressed the barriers issue in the near-shoring sampled literature.

\subsection{Hypothesis development}

The literature reviews conducted earlier regarding the backand near-shoring decisions, showed only two papers comparing these two relocation strategies - Ancarani et al. (2015) and Zhang and Huang (2012). However, findings that emerged may support the development of research hypotheses regarding the three chosen issues, i.e. contingencies, motivations and barriers to relocation implementation.

Regarding the impact of firm's size, the discussion on the back-shoring sampled literature puts in evidence that larger companies generally have higher financial, managerial and human resources which allow them to have a wider manufacturing footprint at the worldwide level (Anderson et al. 1998; Dobrev and Carroll 2003; Fillis 2001; Johanson and Vahlne 1977; Sharfman et al. 1988) and to remain abroad for a longer time (Ancarani et al. 2015). In this respect, Rasel et al. (2020) state "larger firms can generally consider a greater range of potential location opportunities, including riskier ones away from the home"; in contrast, SMEs "experience higher opportunity costs in searching for alternate locales" (p. 3). Finally, it must be taken into account that while backshoring strategies eliminate coordination costs inherent to produce in a different country, near-shoring ones still imply them. Based on such evidence, we can assume that firm's size will also impact on the preference to maintain production activities abroad instead of back-shoring them. Therefore, we speculate as follows:

H1. The smaller the company, the higher the propensity to back-shore instead of near-shore.

Notwithstanding that we recognize several issues were proposed for both motivations and barriers, the exploratory nature of this paper induced us to focus on a reduced number of elements for both categories. Therefore, we decided to cover the most widely studied ones or those having more interest in terms of future scenarios, although others (such as cultural differences) may also be relevant.

As noted earlier, the only commonality between the two investigated streams of literature is with regard to motivations which may induce companies to implement a relocation of second degree. However, further speculations may be developed on this issue. More specifically, while cost-related issues seem not to be relevant in discriminating between relocation to the home country instead of to the home region, the back- 
shoring alternative should be preferred when the home country offers higher comparative advantage with respect to the near region issues.

A first comparative advantage motivating the preference for back-shoring is related to the so-called "made in effect", i.e., the higher value products gain when produced in the home country instead of abroad. This reshoring driver is among the most cited by both scholars and managers of reshoring companies (Barbieri et al. 2018) since it positively impacts on customers' willingness to buy (Grappi et al. 2015). Therefore, we derive:

H2a. The higher the relevance perceived by the reshoring company in terms of the "made in effect", the higher the propensity to back-shore.

As noted earlier, firm's capabilities - especially those regarding manufacturing activities - have a critical role in influencing the readiness of reshoring companies (Nujen et al. 2019). Obviously, such capabilities may be owned either by the reshoring company or its suppliers. However, during the off-shoring period, companies may have lost such capabilities in the home country (Nujen et al. 2018) and the local supply chain may have been dismissed (Ashby 2016; Boffelli et al. 2020). This may represent a barrier to manufacturing back-shoring, especially for small-sized firms (such as those generally operating in the footwear industry), since it may be too challenging and/or time-consuming to internally redevelop such capabilities (Nujen and Halse 2017). Therefore, small companies may be obliged to leverage on local contractors owning the key manufacturing resources (Lampón and González-Benito 2019) needed to rapidly bring operations back. Therefore, we hypothesize as follows:

$\mathrm{H} 2 \mathrm{~b}$. The higher the relevance perceived by the reshoring company in terms of "availability of skilled contractors", the higher the propensity to back-shore.

As already pointed out, scholars and policy makers postulate that industrial policies will have a growing importance in the post-Covid 19 pandemic scenarios of GVCs' reconfiguration. In this respect, it must be noted that firms may find such government aids not only in policies specifically enacted for this aim, but in any other policy or aid that governments implement that can affect the firm's decision, such as the availability of industrial areas, loans to promote growth, availability of skilled workforce. Therefore, we formulate the following hypothesis:

$\mathrm{H} 2 \mathrm{c}$. The higher the relevance perceived by the reshoring company in terms of "availability of government aids", the higher the propensity to back-shore.
Moreover, among the different typologies of expected barriers to the implementation of reshoring strategies, those related to the availability of manufacturing resources (either at the firm's level or at the supplier base one) become the most critical for production relocation. Therefore, it may be assumed that companies deciding where to relocate earlier offshored production activities take into account the set of internal competences and relationships developed with local business partners they own in the home country (Baraldi et al. 2018). Therefore, we focus on them and raise the following hypotheses:

H3a. Companies that perceive more difficulties in finding skilled contractors when relocating off-shored production activities will prefer the back-shoring alternative to the near-shoring one.

H3b. Companies that perceive higher barriers to developing internal manufacturing competences in the country where they have relocated off-shored production activities will prefer back-shoring to near-shoring.

\section{The footwear industry}

The footwear industry is an interesting case to study manufacturing relocations at the world-wide level. It must be noted that it is a labour-intensive sector which throughout the 1990s and 2000s was mostly displaced towards emerging economies, particularly China and other Asian countries (see Belso-Martínez 2008 for details). This change in the location is not surprising, since within the traditional framework, labour-intensive tasks will find their optimal location in those countries where labour is relatively more abundant and cheap. However, as Lowder (1999) noted, the full displacement of the activity cannot be explained solely on the basis of the search for lower costs, but factors such as the role of intermediaries and the general features of each country must also be taken into account .

In both Spain and Italy (as well as in other Southern European countries), the footwear industry has a long tradition that can be traced back to the second half of the nineteenth century; however, the massive expansion took place in the second half of the twentieth century, with many similar features between them. According to Eurostat, Spain and Italy accounted respectively for $13 \%$ and $48 \%$ of the total value of the EU28 footwear industry in 2017; however, while the average price for Italian output is $54.9 € /$ pair, the Spanish one is $24.6 € /$ pair.

The footwear industry is characterized by being organized in industrial clusters/districts in both investigated countries. As is well known, clusters/districts form an environment where knowledge, expertise and ideas flow more quickly 
among participants. Moreover, such flows also generate externalities that reinforce companies operating within the same geographic area. The actual situation was that, in both countries this industry exploited the advantages provided by the clusters/districts they shaped, becoming a success story till the 1980s/90s. The success of the footwear industry in these two countries contrasts with other advanced economies such as, for example, the US, where Freeman and Kleiner (2005) report that while consumption increased from 735 million pairs in 1966 to 1219 billion in 1996, production shrank from 639 million to 120 million respectively with employment losses close to $90 \%$, confirming that their competitiveness was not solely based on their costs.

The internationalization strategies implemented by Italian and Spanish footwear companies are characterized by some relevant differences. First of all, Italian firms started their exports in the 1950s while the Spanish ones did it one decade later. At the same time, while the former adopted a differentiation strategy based on innovative design and perceived product quality (Camuffo et al. 2006); the latter implemented a cost leadership approach (Fontana and Miranda 2017). The two sets of companies also differed - at least in the initial stages of their international processes - in terms of target export markets. While Italian footwear firms focused on the European market, Spanish firms focused on the US, since at the time (1960s) Spain was not still a member of the European Economic Community.

The emergence of China, as well as other Asian economies in the footwear industry, thanks to international trade liberalisation and China's membership of the World Trade Organization (WTO), created a serious challenge that many firms could not face on the basis of their traditional advantages. Although their competitiveness was not solely based on price (Lowder 1999), Western companies were required to compete with products manufactured in Asian low-wage countries. This induced Italian and Spanish companies to evaluate the relocation of manufacturing activities to low cost countries. In this respect, it must be noted that the production process of shoes has a clear separation in its different stages that makes it easier to carry on producing them in different premises or even by different agents. First, based on a last, the specific design is established and the shapes of the different pieces that are needed to produce such a design; second, the pieces are cut using different techniques (e.g., from knife to laser); third the different pieces are prepared to be joined and later these are stitched throughout different procedures (sewing, gluing, warming,...) adding eyelets (if there are any) and similar; next the upper part, once assembled, is glued/sewed to the sole and, again different techniques are available according both to the model as well as the firm's technology; finally a treatment is given to improve the final appearance of the footwear. As can be seen, the design is the more creative stage and the one where the most remarkable differentiation element lies, although in all the other stages skilful abilities are needed that can compromise the whole product. Besides, different technological alternatives exist for phases such as cutting or finishing, which do not need highly sophisticated machinery, while assembling the upper part to the sole requires more advanced production systems.

The fact that some phases (such as cutting the parts or stitching them) are easily separable from the rest, makes it easy to divide the production process among different agents. While this strategy was usually adopted inside the firm's cluster/districts, when the global pressure in terms of price competitiveness grew, footwear companies moved part of the production process to countries with lower labour costs. Given the available firms in several host countries (e.g., Brazil, China, Romania) and to avoid the complexities of managing a production process split between distant locations, most of the firms retained the design phase in the home country and off-shored all the other tasks (eventually with the exception of some of the finishing tasks). Italian firms did it first, with some cases in the late 1970s and more widely in the 1990s, firstly to countries in the Balkans and later to Asia (Amighini and Rabellotti 2006; Constantin et al. 2010). In contrast, in Spain the production off-shoring (mainly addressed to Asian countries) process started in the late 1990s and has been increased in the first years of the twenty-first century (Gómez et al. 2006). Both Italian and Spanish firms were mostly SMEs, so the possibilities of investing in premises abroad were limited (both for financial reasons as well as for the managerial complexity that implies). Consequently, non-equity internationalization strategies become the mostly widely used, and specifically subcontracting.

This change in the industry of both countries led to an important reshape of their respective industrial districts that combined the local presence with an internationalization strategy that involved the displacement of parts of the production process to distant locations (Amighini and Rabellotti 2006; Tortajada et al. 2005) which seems to be the case with other labour-intensive industries (Scott 2006). It supposed the evolution of an industrial structure, where most of the exchanges happened inside the national districts of both countries, towards the design and participation in the GVCs of this product. In comparison with hi-tech products or firms that use proprietary technologies, in the footwear industry there is no specific technology involved, so there is a low likelihood that know-how is leaked to other firms or competitors. Besides, access to intermediaries and retailers is an important element, which reduces the risk that other manufacturers could replicate/imitate the models and serve the market. This last factor is especially important for Italian firms that had made design and brand recognition part of their competitive strategy and therefore were not specially constrained to be involved in subcontracting abroad as part of their production. 
It is interesting to remark that the internationalization process of the production, and the development and inclusion of the GVCs of the footwear industry, did not suppose the full dismantling of the original production clusters in either of the two home countries, and that producers of the different stages of production. This issue becomes important when the company decides to critically re-evaluate the production offshoring decision and implement the back-shoring alternative.

Finally, it must be acknowledged that the pressure for even lower production costs still remains in the footwear industry. In this respect, it is worth noting that in the last two decades China is - at least partially - losing its attractive role as a "global factory" for the footwear industry. In this respect, Huang and Chen (2016) found that while in 2001 China manufactured $40 \%$ of the world's production of shoes, in 2010 the level was reduced to $34 \%$ while in Vietnam production grew to $37 \%$. So, we can conclude that the world footwear industry is under important changes that modify the appeal of some countries to host it, for a large array of reasons. As indicated in the Introduction, cases of firms that had offshored but are reconsidering and modifying their location are important in this industry, and empirical research is needed to highlight the relevance of some of the possible explanations.

The next sections present an empirical analysis that will help us to know more about the motives that lead firms to near- or back-shoring.

\section{Sample description and research methodology}

In order to reach the research aims earlier presented, data regarding Spanish and Italian companies have been collected through a common questionnaire delivered in both countries. More specifically, the questionnaire was articulated in three main parts, the first of which collects information on the surveyed firms in terms of size (e.g., firm' sales, number of employees), international propensity (valuated in terms of percentage of exports on total sales), target markets (economic, medium, medium-fine, fine and luxury) and sources for competitive advantage (quality service and delivery time, design, advertising, brand, production costs). The second section was addressed to the initial off-shoring strategy; therefore, questions were regarding the "what" of the first relocation decision (e.g., which product line(s) and/or production phase(s) were offshored), the "why" (e.g., motivations/drivers) based on the existing literature on reshoring that will allow us to test the raised hypotheses, and the "where" (chosen host country). Finally, companies were requested to cite the problems/ barriers (if any) they experienced when staying abroad. The third and final part of the questionnaire was focused on the back-/near-shoring decisions which have been investigated according to the same variables adopted for the off-shoring phase.
As far as the Spanish companies are concerned, the questionnaire was addressed to footwear manufacturers across all the country (even though $60 \%$ of them are located in the Alicante industrial district). The average size of the responding firms is similar to that of the whole population ( $80 \%$ with fewer than 20 employees) and with a high presence in international markets (50\% of the firms export over $50 \%$ of their total sales). After receiving 103 completed questionnaires, attention was focused on the 33 that had implemented off-shoring strategies. All of them completed the part of the questionnaire specifically focused on the back- and near-shoring decisions, and 15 out of the 33 companies declared to have implemented both backand/or near-shoring strategies.

With respect to the Italian companies, a list of 17 companies that implemented relocation of second degree decisions (including the further off-shoring one) was obtained from the Italian Association of Shoemakers. The list was derived from a previous survey among the Association's 600 members which had obtained a response rate higher than $30 \%$. After contacting each of the 17 companies, 10 of them declared to have implemented back- and/or near-shoring strategies (while the other seven implemented only further off-shoring decisions). All back- and near-shoring companies were requested to complete the same questionnaire sent to the Spanish companies.

The use of the same questionnaire allowed us to develop a two-country analysis with guarantees that firms were answering the same questions and therefore the results were comparable. In order to avoid any subjectivity by the firms on whether a country is considered in the same region as the home country or not, firms were requested to specifically cite the country where they relocated after the initial off-shoring decision. Based on such data, we verified if the new host country was consistent with the near-shoring conceptualization.

Based on questionnaire completed by the 25 companies ( 15 Spanish and 10 Italian), a total number of 41 relocation of second degree decisions was found, of which 31 were backshoring and 10 near-shoring. The near-shoring cases implied the relocation of the production, among the Italian firms towards Eastern Europe and the Balkans with one case to Portugal, while among the Spanish firms, some cases to Morocco were also observed. Therefore, each surveyed company implemented 1.6 decisions on average. This finding enlarges previous evidence by Fratocchi et al. (2015) in terms of back-shoring strategies, showing that multiple relocation decisions also consider the near-shoring phenomenon. In this respect, no differences were found between the two countries; however, the multiple relocation decisions implemented by Italian companies were generally hybrid, i.e., they simultaneously implemented both the back- and near-shoring alternatives. Finally, the multi-shoring strategy has been mainly implemented by Italian medium-sized firms ( 1.8 decisions by companies) while Spanish firms do not show any relevant differences according their size ( 2.3 decisions on average). 
Table 1 Sample characterization by firm's size and relocation strategy

\begin{tabular}{|c|c|c|c|c|c|c|c|c|c|}
\hline \multirow[t]{2}{*}{ Size } & \multicolumn{3}{|c|}{ Italy (No. of decisions) } & \multicolumn{3}{|c|}{ Spain (No. of decisions) } & \multicolumn{3}{|c|}{ Total (No. of decisions) } \\
\hline & Firms & Back & Near & Firms & Back & Near & Firms & Back & Near \\
\hline Large & 4 & 1 & 5 & & & & 4 & 1 & 5 \\
\hline Medium & 4 & 5 & 2 & 4 & 7 & 2 & 8 & 12 & 4 \\
\hline Small & 2 & 2 & & 4 & 8 & 1 & 6 & 10 & 1 \\
\hline Micro & & & & 7 & 8 & & 7 & 8 & \\
\hline Total & 10 & 8 & 7 & 15 & 23 & 3 & 25 & 31 & 10 \\
\hline
\end{tabular}

The "off-shoring time", i.e., the year when the company started to relocate their production activities abroad, emerges as another difference between Italian and Spanish firms. Except for two isolated cases in the 1970s and 1980s (one for each country), Italian firms have generally off-shored during the 1990s (8 out of 10) while Spanish ones only in the first decade of the twenty-first century ( 7 out of 15 ), which is in accordance with the results presented by Fontana and Miranda (2017) on their analysis of the whole industry. Since Spain was generally considered one of the low labour cost countries in Western Europe (along with Portugal and Greece), the latter evidence might be explained with the opening of the WTO to China in 2002. As noted earlier, in Section 3, this event increased the price pressure on European companies (especially those that had in their low labour costs a source of competitive advantage) and pushed them to off-shore (Verdu et al. 2012).

Comparing the main features of two sub-samples (Table 1), Italian firms are larger; moreover, they implemented the two relocation strategies under analysis almost equivalently (8 back- vs. 7 near-shoring evidence) while Spanish companies rarely near-shored ( 23 back- vs. 3 near-shoring evidence).

Italian companies are also characterized by a higher level of exports (Table 2); this finding may be - at least partially explained by their larger size.

When considering the market positioning, Italian companies are more focused on the medium and high priced niches while Spanish ones are generally focused on low-end ones (Table 3). Such findings are indirectly confirmed by statistics on the average price of exported footwear cited earlier in the industry presentation. Even if companies from both countries are mainly focused on a single product line, Italian firms are characterized by a wider product mix (4 out of 10 address more than one target against 4 out of 15 in the Spanish subsample). Once more, the finding may be, at least partially, explained by their smaller size.

The empirical analysis to test the previously raised hypotheses (Section 2.3) is developed on data provided by the survey described earlier of firms from the two countries. The aim is to assess, by means of statistical tests, whether some of the firms' are different between firms that back-shored rather than the one that near-shored (such as size, H1), or whether the motivations and barriers to implement a second degree relocation differ for the two groups.

Given there are two kind of variables to test, i.e., whether they are differently distributed in the group of back-shoring companies than in the near-shoring ones, two different tests will be used. For binary variables (such as being small/ medium-sized or large) a Fisher's exact test for the differences between the two groups of interests was adopted. For variables measured according to a Likert scale from 1 to 5 , the hypotheses of differences between companies that nearshored and those that back-shored has been evaluated using a test of equality of means. This test does not impose equality of variances between the two groups. In Table 4 , it is indicated whether the hypotheses that the two means are equal (i.e., the characteristic is equally important for back-shoring and near-

Table 2 Sample characterization by export intensity and relocation strategy

\begin{tabular}{|c|c|c|c|c|c|c|c|c|c|}
\hline \multirow[t]{2}{*}{$\%$ export } & \multicolumn{3}{|c|}{ Back-shoring } & \multicolumn{3}{|c|}{ Near-shoring } & \multicolumn{3}{|l|}{ Total } \\
\hline & Italy & Spain & Total & Italy & Spain & Total & Italy & Spain & Total \\
\hline $0 \%$ & & 4 & 4 & & & & & 4 & 4 \\
\hline$<10 \%$ & & 1 & 1 & & 1 & 1 & & 2 & 2 \\
\hline $10-25 \%$ & 1 & 5 & 6 & 2 & 2 & 4 & 3 & 7 & 10 \\
\hline $25-50 \%$ & 1 & 6 & 7 & 2 & & 2 & 3 & 6 & 9 \\
\hline$>50 \%$ & 6 & 7 & 13 & 3 & & 3 & 9 & 7 & 16 \\
\hline Total & 8 & 23 & 31 & 7 & 3 & 10 & 15 & 26 & 41 \\
\hline
\end{tabular}


Table 3 Sample characterization by targets (companies may operate in more than one)

\begin{tabular}{llll}
\hline & Italy & Spain & Total \\
\hline Economic & 1 & 9 & 10 \\
Medium & 3 & 7 & 10 \\
Medium/Fine & 7 & 3 & 10 \\
Fine & 4 & 2 & 6 \\
Luxury & 1 & 1 & 2 \\
Total firms & 16 & 22 & 38 \\
\hline
\end{tabular}

shoring firms) is accepted or rejected at the standard significance levels.

\section{Findings}

The results of the statistical analysis presented in Table 4 allow us to differentiate the groups of firms that relocated to near countries ("near-shorers") from those that returned manufacturing activities to their home country ("back-shorers"). The characteristics have been grouped into the three dimensions we selected for our research hypotheses: i) contingency issues, ii) reasons for reshoring and iii) barriers to reshoring.

As far as contingencies are concerned, we focused attention on the size issue. Data in Table 4 show that near-shorers are larger than back-shorers. Therefore, $\mathrm{H} 1$ is confirmed. This finding is consistent with the idea that larger companies generally have higher financial, managerial and human resources, which allow them to have a wider manufacturing footprint at the worldwide level (Anderson et al. 1998; Dobrev and Carroll 2003; Fillis 2001; Johanson and Vahlne 1977; Sharfman et al. 1988). At the same time, larger companies may accept higher levels of managerial risk (Rasel et al. 2020), therefore they may accept maintaining production abroad (though in the home region) when the initial offshoring strategy emerged as no longer suitable. In this respect,
Ciabuschi et al. (2019) proposed that the higher uncertainty derived from the off-shoring strategy failure increases the firm's perceived risk. Therefore, if the reduced resources owned by a company prevent it from managing this higher risk, back-shoring decisions will be more likely.

Regarding reshoring motivations, the "made in" effect emerged as not statistically different between both groups of companies (back-shorers vs. near-shorers). Therefore H2a is rejected. This unexpected finding could be due to the fact that the consumers perceive the product value more on the basis of the product brand than of the country where it is actually manufactured. At the same time, customers in the Economic and Medium market niches (Table 3) are often more interested in the product price than in the country of origin, which is considered to be a proxy of the quality issue (more relevant for Medium/Fine and Fine targets). Finally, several customers are conscious that the "made in" label may also be adopted at least in Europe - for products whose relevant production phase was located abroad. In the footwear industry, for instance, a pair of shoes may be labelled as "made in Italy" even if the upper production is performed in other European countries (e.g., Romania).

The second motivation we analysed concerns the availability of skilled contractors. It shows huge differences between the two subsets. Firms that back-shored indicate this was a very relevant driver of their decision to relocate at the home country (4.4 points out of 5) while for firms that near-shored its importance is evaluated as medium (just 2.8 points out of 5). Therefore, H2b is confirmed. This finding may be explained, at least partially, according to a risk perspective. More specifically, Ciabuschi et al. (2019) proposed that the higher the relative risk of host-country (inadequacy of local suppliers) compared to the home-country, the higher the likelihood of reshoring. In other words, when companies suffer lower quality than desired from foreign suppliers, they opt for back-shoring since they already know what national contractors may offer. In contrast, they do not accept a further trial in
Table 4 Comparison of backshoring and near-shoring activities

\begin{tabular}{|c|c|c|c|c|}
\hline & Back-shoring & Near-shoring & Test & \\
\hline \multicolumn{5}{|l|}{ Firm characteristics } \\
\hline Size $(\%$ of $\mathrm{L} / \mathrm{M} / \mathrm{S})$ & $3,2 / 38,7 / 58,1$ & $50 / 40 / 10$ & 0.011 & $* *$ \\
\hline \multicolumn{5}{|l|}{ Motivations } \\
\hline "Made in" effect & 3000 & 3000 & - & \\
\hline Availability of skilled contractors & 4348 & 2833 & 2362 & $*$ \\
\hline Government aids & 1722 & 1143 & 2274 & $* *$ \\
\hline \multicolumn{5}{|l|}{ Barriers } \\
\hline Find new contractors/employees & 2706 & 1400 & 2991 & $* *$ \\
\hline Creation new manufacturing competences & 3286 & 1000 & 3200 & $* *$ \\
\hline
\end{tabular}

*,** Indicate acceptance of the hypothesis of different values between the two groups at 90 and $95 \%$ of confidence respectively 
a new foreign country, even though it is located in the home region, since that will require another search with its inherent costs and risks.

Finally, although the relevance of policies that governments develop and firms value as an aid to relocating to their home country is really low between the two groups of companies (back-shorers vs. near-shorers), the difference is statistically significant. More specifically, as expected, it is in favour of relocating the production to the home country instead of in neighbouring countries. Therefore, $\mathrm{H} 2 \mathrm{c}$ is accepted. This finding confirms that government aids may contribute to the reshoring decision but they are not its main driver; in other words, they assume the role of an "enabling factor" (Boffelli and Johansson 2020). It also confirms the idea that industrial policy aimed at attracting reshoring companies should include not only financial aid but also improved service provision for undertaking business activities. Among them, helping companies to find local contractors may represent a critical factor. In this respect, it is interesting to refer to the experience of the United Kingdom Trade and Investment (UKTI) which in 2014 was requested to support UK companies aiming to relocate by identifying local suppliers in order to (re-)develop a national supply chain (UK Government 2014). At the same time, the Manufacturing Advisory Service - an organization funded by the UK Government Department for Business, Innovation and Skills - offered advice on business strategies, innovative practices, efficiency of production processes and supply chain services to UK SMEs aiming to become suppliers of reshoring companies. However, the Manufacturing Advisory Service was closed in 2015 and the UKTI service ended in 2016; after then, initiatives aimed at boosting reshoring initiatives were partially included in the wider programme of the Innovate UK agency. Finally, the support for supplier searches is actually promoted by the "Reshoring UK" initiative which has been established as a private league of industrial associations.

Once the firm decides to relocate the production earlier off-shored, this decision may encounter barriers to its implementation. Given the focus on manufacturing activities, the availability of skilled contractors and/or the possibility to (re-)develop internal manufacturing competences become critical issues. Both elements show a positive and significant difference between the two investigated groups. More specifically, companies expected to experience such types of barriers preferred to back-shore than near-shore. Therefore, $\mathrm{H} 3 \mathrm{a}$ and $\mathrm{H} 3 \mathrm{~b}$ are confirmed. In this respect, it is worth noting that companies declaring their back-shoring strategy have been boosted by the availability of skilled contractors at the location where they off-shored (H2b) and did not experienced any problems with this issue after relocating production to the home country. In other words, their previous evaluation of available resources emerged as correct after the relocation of second degree alternative was implemented.

\section{Concluding remarks and implications}

Off-shoring is a strategy that manufacturing firms (not only those belonging to the footwear industry) have widely implemented, especially during the last decades of the twentieth century. However, firms' behaviour is showing us that the location change in their production tasks is not permanent and they often reconsider it. Among the second degree relocations, companies may decide to return to their home country (back-shoring) or to neighbouring ones (near-shoring).

Although the academic literature has increasingly paid attention to second degree relocation decisions, there is a lack of analysis on the variables that may influence companies to choose between the back-shoring and near-shoring alternatives. This issue is quite relevant not only for the firm's management but also for policy makers interested in attracting the flow of companies revising their initial off-shoring decision. It has become even more important since the Covid-19 pandemic which is likely to induce a diffused reconfiguration of GVCs (Gereffi 2020; Strange 2020; UNCTAD 2020). In this respect, De Meyer (2020) recently pointed out that Covid-19 renewed the primacy of politics over economics. Moreover, the World Economic Forum has specifically recommended national governments to "aggressively evaluate near-shore options to shorten supply chains and increase proximity to customers" (Betti and Hong 2020).

In this paper we have analysed some of the issues that can influence whether firms back-shore or near-shore, namely contingencies, motivations and barriers. We found back-shoring companies are generally smaller and were boosted by the availability of suppliers and government aids but not by the opportunity to leverage on the "made in" effect. As far as barriers are concerned, the scarcity of competences owned by either the company or the contractors generally induces a preference for relocation to the home country than to near-shore in the home region. Our findings seem to show that some variables affect the firm's decision to implement either a back- or a nearshoring alternative. More specifically, owned resources (where size acts as a proxy) and the perceived risk (e.g., the one related to scarcity of competences) seem to highly influence the firm's decision. However, this paper is mainly of an exploratory nature; moreover it is based on a relatively small amount of evidence from a single industry. While we state that our results give the basis for future research, we recognize further studies should be developed to investigate other industries and countries. In doing so, in their studies scholars should also take into 
account the characteristics of the set of neighbouring countries and the governance modes adopted by sampled firms when they off-shore and when they relocate the production activities. Moreover, future studies should carefully evaluate if the initial off-shoring decision and the relocation of second degree regard the entire production process and/or product lines or were inspired by a selective and/or incremental approach (Baraldi et al. 2018; Boffelli et al. 2020). Finally, specific attention should be paid to the cultural issue, in order to verify, for instance, if near-shoring strategies are supported by reduced physical distance.

Notwithstanding its exploratory nature, the paper also offers some preliminary insights for managers, since it highlights which variables may influence their decision-making process when considering the second degree relocation alternatives. More specifically, they should take into account not only the firm's characteristics (such as size) but also the motivations and barriers that characterize the reshoring decisionmaking process (Boffelli and Johansson 2020). This is consistent with the recent findings by Boffelli et al. (2020) and Gray et al. (2017) which show SMEs often implement relocation of second degree based on a "trial and error approach". Finally, managers are requested to pay specific attention to production capabilities, as recently stated by Lampón and GonzálezBenito (2019).

Finally, our contribution also offers some preliminary insights for policy makers, who will be requested to (re)design their industrial policies to cope with the transition from GVCs to either regional (near-shoring) or domestic (back-shoring) ones. In this respect, traditional financial aids should be coupled woth other typologies of incentives, such as support for the local suppliers' search and selection.

\section{Appendix}

\section{Sampled literature: criteria and main characteristics}

In order to define the theoretical background, we selected Scopus indexed journal articles published in the English language until 2020 August. More specifically, in order to analyse the back-shoring phenomenon we checked the title, abstract and keywords for the following terms: i) "reshor*"; ii) "re-shor*"; iii) "backshore*"; iv) "back-shor*"; v) "backreshor*"; iv) "back-sourc*".

We found a total number of 261 journal articles; after all the co-authors had carefully read the full text of these articles, they found one paper (Mohiuddin et al. 2019) that refers to the further off-shoring phenomenon instead of the back-shoring one; therefore it was eliminated. Moreover the following excluding criteria were adopted:
- journal articles focusing on back-shoring of firms operating in industries different from manufacturing ones (e.g., ICT companies);

- documents published in sources without peer review systems;

- journal articles in which the searched terms are used to indicate a different concept from the one of interest (for instance, some of the keywords belonging to the reshoring concept are used with different meanings in the maritime and building engineering research fields);

- documents referring to functions other than operations (e.g., human resources and research and development (R\&D)).

Based on these criteria and after eliminating duplications, the final sample contains 142 documents regarding the backshoring phenomenon (see Table 5).

At the same time, to describe the state-of-the-art of nearshoring literature, we replicated the same research methodology checking the title, abstract and keywords for the following terms: i) "near/shor*"; ii) "nearshor*" iii) "near-reshor*".

We collected a total of 40 documents. Exclusion criteria were defined considering that the term near-shoring has been adopted with different meanings in the literature of different subject areas. For instance, it is used in the engineering and environmental science fields of study to refer to the littoral zone, i.e., "the part of a sea, lake, or river that is close to the shore" (https://en.wikipedia.org/wiki/Littoral_zone). Therefore, we excluded all documents regarding environment-related conceptualizations of the near-shoring term. Regarding the international business and supply chain management research areas, the term has been adopted with further twofold meanings: a) a specific type of off-shoring strategy addressed to a host country located in the home region (Hutzschenreuter et al. 2011; Kamann and van Nieulande 2010; Kvedaravičiené 2008; Shamis et al. 2005; Slepniov et al. 2013); b) a "relocation of second degree" (Barbieri et al. 2019) in an host country located in the home region. In this respect, it is worth nothing that at least one journal article simultaneously adopts the term nearshoring to refer to both concepts (Huq et al. 2016). In this paper we assume as a reference the second concept of near-shoring strategies, since we are interested in analysing post off-shoring firm's decisions (Bettiol et al. 2019). Moreover, we excluded articles focusing on the relocation of service companies (five documents) and/or firm's functions that were different from the production one.

A final number of 10 articles were then considered as relevant for defining the theoretical background for nearshoring; however, six of them also refer to the backshoring phenomenon, therefore the total sampled literature is $142+10-6=146$. The main characteristics of the sampled literature on near-shoring are summarized in Table 6 . 


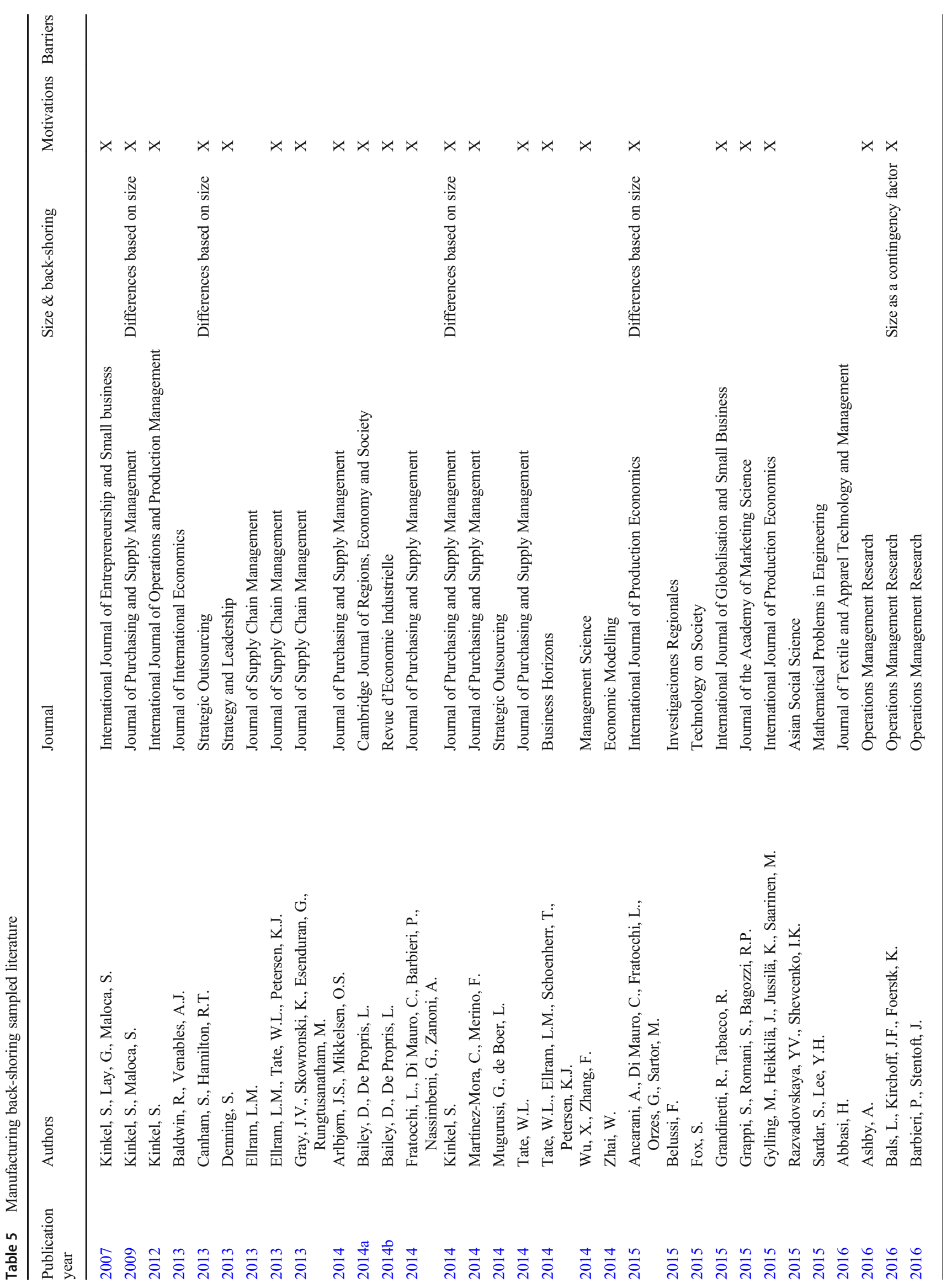




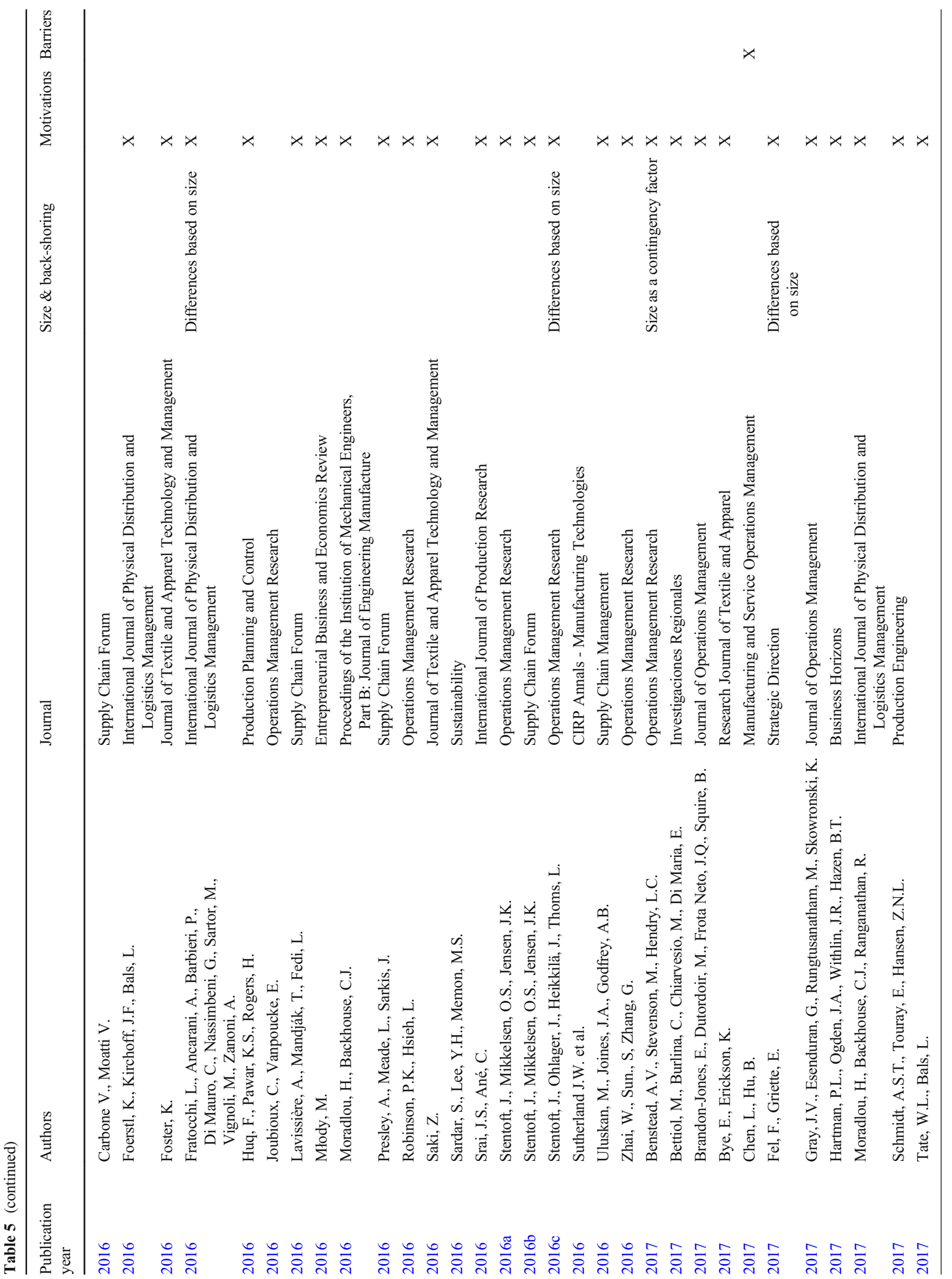




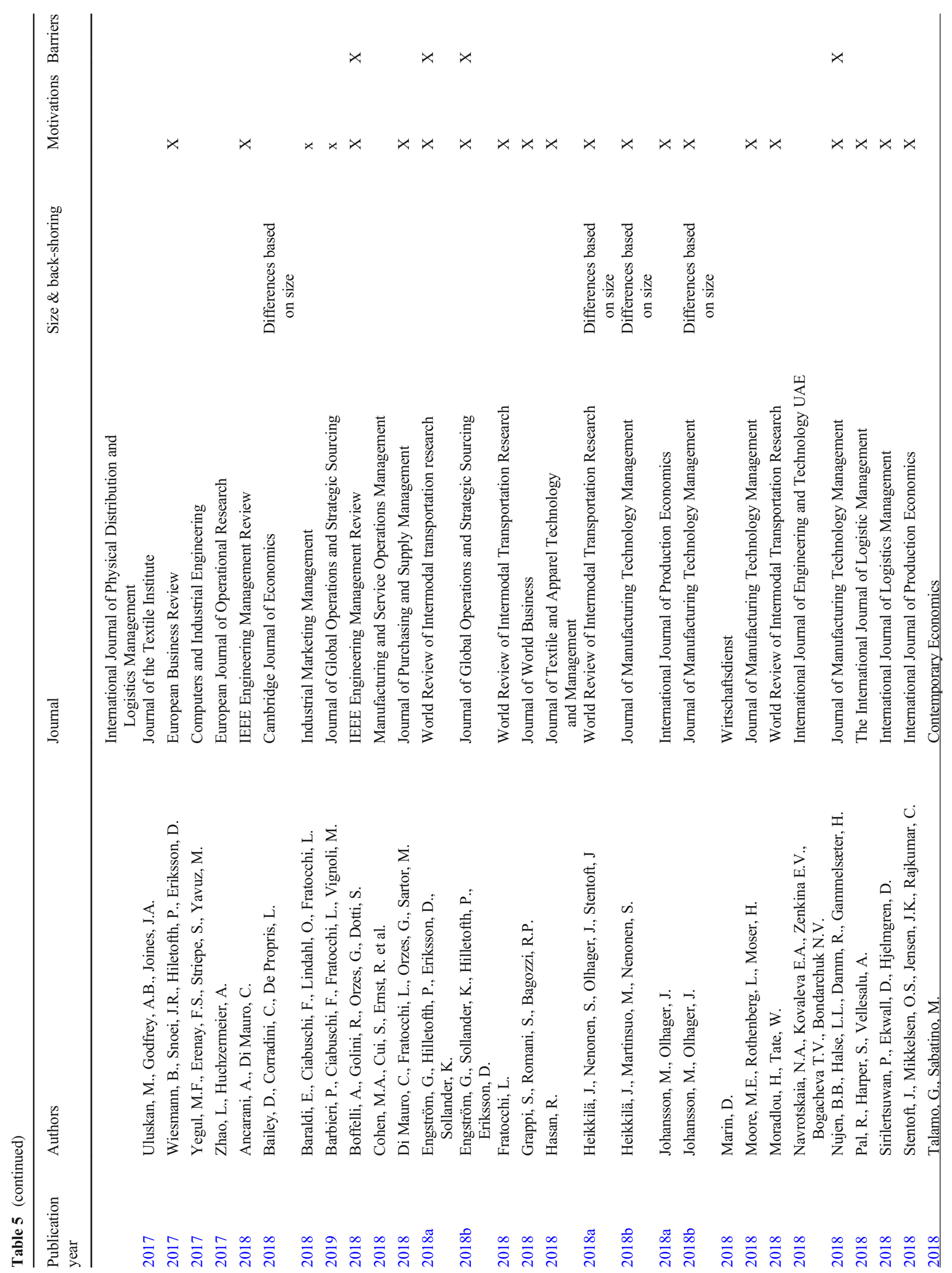




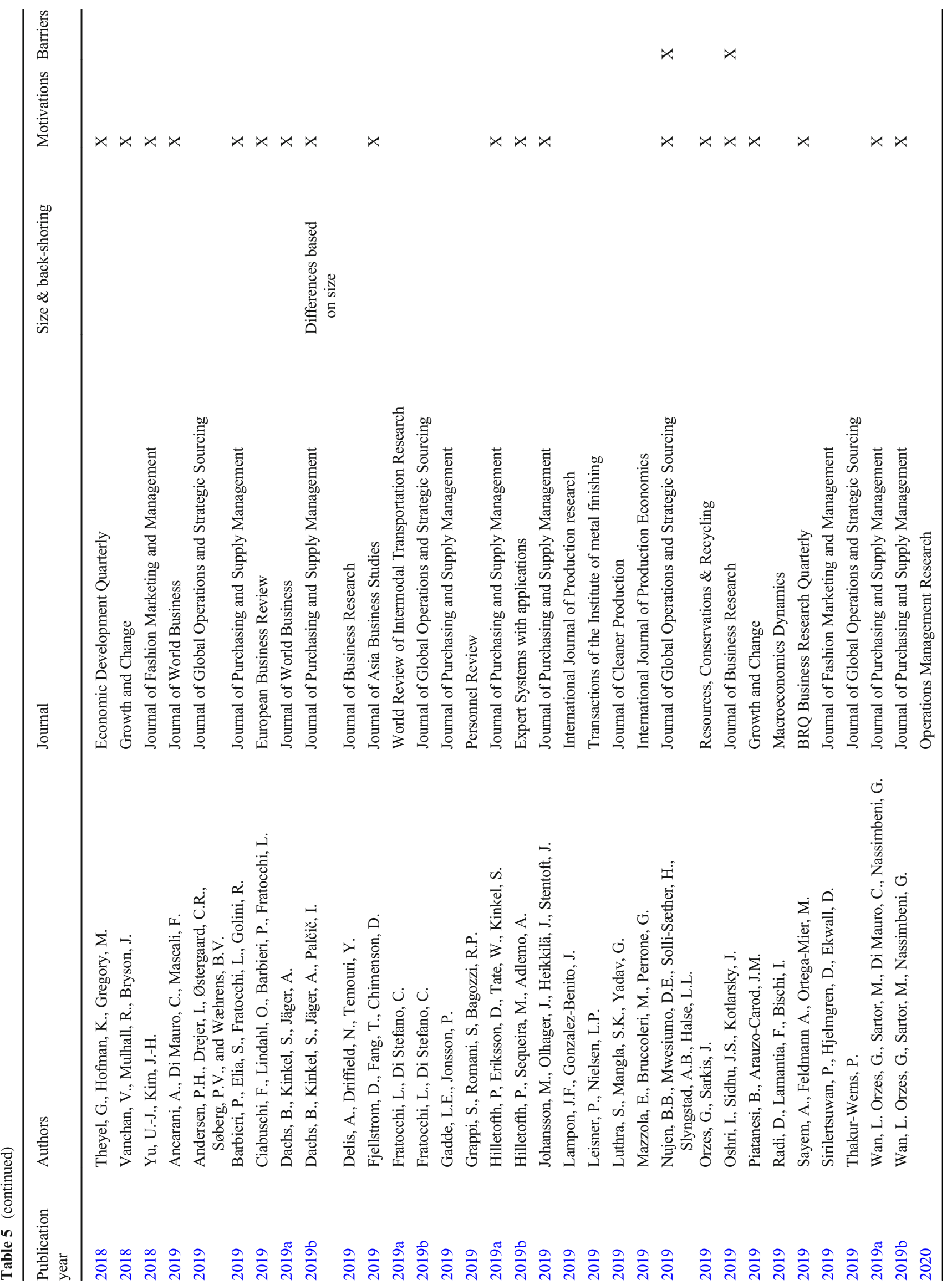




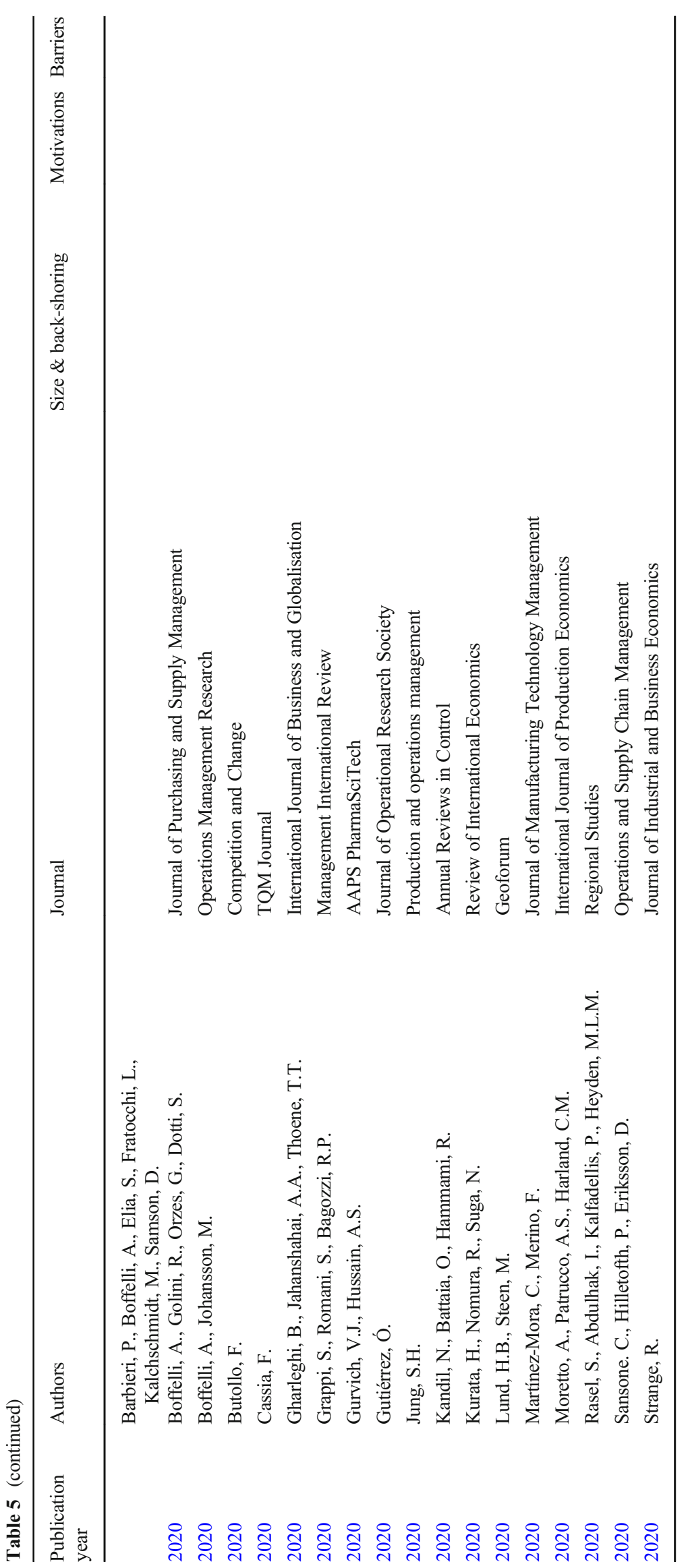


Table 6 Manufacturing near-shoring sampled literature

\begin{tabular}{|c|c|c|c|c|c|c|}
\hline Year & Author(s) & Journal & $\begin{array}{l}\text { Included in back- } \\
\text { shoring literature }\end{array}$ & $\begin{array}{l}\text { SME and } \\
\text { near- } \\
\text { shoring }\end{array}$ & Motivations & Barriers \\
\hline 2012 & Johnson, W. & Printed Circuit Design \& Fab & & & $\mathrm{X}$ & \\
\hline 2015 & Baldassarre, F., Campo, R. & $\begin{array}{l}\text { International Journal of Supply } \\
\text { Chain Management }\end{array}$ & & & & \\
\hline 2015 & Belussi, F. & Investigaciones Regionales & YES & & & \\
\hline 2016 & Ashby, A. & Operations Management Review & YES & & $\mathrm{X}$ & \\
\hline 2016 & Huq, F., Pawar, K. S., Rogers, H. & Production Planning \& Control & YES & & $\mathrm{X}$ & \\
\hline 2017 & $\begin{array}{l}\text { Hartman, P. L., Ogden, J. A., } \\
\text { Wirthlin, J. R., Hazen, B. T. }\end{array}$ & Business Horizons & YES & & $\mathrm{X}$ & \\
\hline 2017 & Wu, P., Jin, Y., Shi, Y., Shyu, H. & $\begin{array}{l}\text { International Journal of } \\
\text { Production Economics }\end{array}$ & & & & \\
\hline 2019 & Gadde, L.-E., Jonsson, P. & $\begin{array}{l}\text { Journal of Purchasing and } \\
\text { Supply Management }\end{array}$ & YES & & & \\
\hline 2019 & Hilmola O.-P., Tolli A., Panova Y. & Economy of Region & & & $\mathrm{X}$ & \\
\hline 2019 & Piatanesi, B., Arauzo-Carod, J.M. & Growth and Change & YES & & & \\
\hline
\end{tabular}

\section{References}

Abbasi MH (2016) It's not offshoring or reshoring but right-shoring that matters. J Text Appar Technol Manag 10(2):1-6

Amighini A, Rabellotti R (2006) How do Italian footwear industrial districts face globalization? Eur Plan Stud 14(4):485-502

Ancarani A, Di Mauro C (2018) Reshoring and industry 4.0: how often do they go together? IEEE Eng Manag Rev 46(2):87-96

Ancarani A, Di Mauro C, Fratocchi L, Orzes G, Sartor M (2015) Prior to reshoring: a duration analysis of foreign manufacturing ventures. Int J Prod Econ 169:141-155

Ancarani A, Di Mauro C, Mascali F (2019) Backshoring strategy and the adoption of industry 4.0: evidence from Europe. J World Bus 54(4): 360-371

Andersen PH, Drejer I, Østergaard CR, Søberg PV, Wæhrens BV (2019) Supplier value creation configurations in high-cost countries. J Glob Oper Strateg Sourc 12(3):429-448

Anderson V, Graham S, Lawrence P (1998) Learning to internationalize. J Manag Dev 17(7):492-502

Arlbjørn JS, Mikkelsen OS (2014) Backshoring manufacturing: notes on an important but under- researched theme. J Purch Supply Manag 20(1):60-62

Ashby A (2016) From global to local: reshoring for sustainability. Oper Manag Res 9(3-4):75-88

Bailey D, De Propris L (2014a) Manufacturing reshoring and its limits: the UK automotive case. Cambridge J Reg Econ Soc 7(3):379-395

Bailey D, De Propris L (2014b) Reshoring: opportunities and limits for manufacturing in the UK-the case of the auto sector. Rev Econ Ind 1(145):45-61

Bailey D, Corradini C, De Propris L (2018) Home-sourcing'and closer value chains in mature economies: the case of Spanish manufacturing. Cambridge J Econ 42(6):1567-1584

Baldassarre F, Campo R (2015) Assessing the global dimension of sourcing: an exploratory study on Italian companies. Int J Supply Chain Manag 4(3):15-24

Baldwin R, Venables AJ (2013) Spiders and snakes: offshoring and agglomeration in the global economy. J Int Econ 90(2):245-254
Bals L, Kirchoff JF, Foerstl K (2016) Exploring the reshoring and insourcing decision making process: toward an agenda for future research. Oper Manag Res 90(3-4):102-116

Baraldi E, Ciabuschi F, Lindahl O, Fratocchi L (2018) A network perspective on the reshoring process: the relevance of the home- and the host-country contexts. Ind Mark Manag 70:156-166

Barbieri P, Stentoft J (2016) Reshoring: a supply chain innovation perspective. Oper Manag Res 9(3-4):49-144

Barbieri P, Ciabuschi F, Fratocchi L, Vignoli M (2018) What do we know about manufacturing reshoring? J Glob Oper Strateg Sourc 11(1): $79-122$

Barbieri P, Elia S, Fratocchi L, Golini R (2019) Relocation of second degree: moving towards a new place or returning home? J Purch Supply Manag 25(3):100525

Barbieri P, Boffelli A, Elia S, Fratocchi L, Kalchschmidt M, Samson D (2020) What can we learn about reshoring after Covid-19? Oper Manag Res 13:131-136

Belso-Martínez JA (2008) Differences in survival strategies among footwear industrial districts: the role of international outsourcing. Eur Plan Stud 16(9):1229-1248

Belussi F (2015) The international resilience of Italian industrial districts/ clusters (ID/C) between knowledge re-shoring and manufacturing off (near)-shoring. Investigaciones Regionales 32:89-113

Benstead AV, Stevenson M, Hendry LC (2017) Why and how do firms reshore? A contingency-based conceptual framework. Oper Manag Res 10(3-4):85-103

Betti F, Hong P (2020) Coronavirus is disrupting global value chains. Here's how companies can respond, World Economic Forum https:// www.weforum.org/agenda/2020/02/how-coronavirus-disruptsglobal-value-chains/

Bettiol M, Burlina C, Chiarvesio M, Di Maria E (2017) From delocalization to backshoring? Evidence from Italian industrial districts. Investigaciones Regionales 39:137-154

Bettiol M, Chiarvesio M, Di Maria E, Di Stefano C, Fratocchi L (2019) What happens after offshoring? A comprehensive framework. International business in a VUCA world: the changing role of states and firms (Progress in international business research, Vol. 14) emerald publishing limited pp 227-249 
Boffelli A, Johansson M (2020) What do we want to know about reshoring? Towards a comprehensive framework based on a metasynthesis. Oper Manag Res 13:53-69

Boffelli A, Golini R, Orzes G, Dotti S (2018) Reshoring decision-making and implementation processes: a multiple-case study. 25th international annual EurOMA conference p 76

Boffelli A, Golini R, Orzes G, Dotti S (2020) Open the box: a behavioural perspective on the reshoring decision-making and implementation process. J Purch Supply Manag 26(3):100623

Brandon-Jones E, Dutordoir M, Frota Neto JQ, Squire B (2017) The impact of reshoring decisions on shareholder wealth. J Oper Manag 49-51:31-36

Butollo F (2020) Digitalization and the geographies of production: towards reshoring or global fragmentation? Compet Change. https:// doi.org/10.1177/1024529420918160

Bye E, Erickson K (2017) Opportunities and challenges for Minnesota sewn product manufacturers. Res J Text Appar 21(1):72-83

Camuffo A, Furlan A, Romano P, Vinelli A (2006) The process of supply network internationalisation. J Purch Supply Manag 12(3):135-147

Canham S, Hamilton RT (2013) SME internationalisation: offshoring, "backshoring", or staying at home in New Zealand. Strategic Outsourcing: An International Journal 6(3):277-291

Carbone V, Moatti V (2016) The missing links in offshoring and backshoring research: learning through the 6 foundational premises of the theory of the supply chain. Supply Chain Forum 17(4):183189

Cassia F (2020) Manufacturing is coming home: does reshoring improve perceived product quality? TQM J 32(6-7):1099-1113

Chen L, Hu B (2017) Is reshoring better than offshoring? The effect of offshore supply dependence. Manuf Serv Oper Manag 19(2):166-184

Ciabuschi F, Lindahl O, Barbieri P, Fratocchi L (2019) Manufacturing reshoring: a strategy to manage risk and commitment in the logic of the internationalization process model. Eur Bus Rev 31(1):139-159

Cohen MA, Cui S, Ernst R, Huchzermeier A, Kouvelis P, Lee HL, Matsuo H, Steuber M, Tsay AA (2018) OM forumbenchmarking global production sourcing decisions: where and why firms offshore and reshore. Manuf Serv Oper Manag 20(3): 389-402

Constantin F, De Giusti G, Tattara G (2010) Strategies of italian firms in Romania: evidence from selected case studies. Transit Stud Rev 16(4):829-847

Dachs B, Kinkel S, Jäger A, Palčič I (2019a) Backshoring of production activities in European manufacturing. J Purch Supply Manag 25(3): 100531

Dachs B, Kinkel S, Jäger A (2019b) Bringing it all back home? Backshoring of manufacturing activities and the adoption of Industry 4.0 technologies. J World Bus 54(6):101017

De Meyer A (2020) It won't be business as usual after Covid-19. The Straits Times. https://www.straitstimes.com/opinion/it-wont-bebusiness-as-usual-after-covid-19

Delis A, Driffield N, Temouri Y (2019) The global recession and the shift to re-shoring: myth or reality? J Bus Res 103:632-643

Denning S (2013) Why agile can be a game changer for managing continuous innovation in many industries. Strategy Leadersh 41(2):5-11

Di Mauro C, Fratocchi L, Orzes G, Sartor M (2018) Offshoring and backshoring: a multiple case study analysis. J Purch Supply Manag 24(2):108-134

Dobrev SD, Carroll GR (2003) Size (and competition) among organizations: modeling scale-based selection among automobile producers in four major countries, 1885-1981. Strateg Manag J 24(6):541-558

Ellram LM (2013) Offshoring, Reshoring and the manufacturing location decision. J Supply Chain Manag 49(2):3-5

Ellram LM, Tate WL, Petersen KJ (2013) Offshoring and reshoring: an update on the manufacturing location decision. J Supply Chain Manag 49(2):14-22
Enderwick P, Buckley PJ (2020) Rising regionalization: will the postCOVID-19 world see a retreat from globalization? Transnatl Corp 27(2):99-112

Engström G, Hilletofth P, Eriksson D, Sollander K (2018a) Drivers and barriers of reshoring in the Swedish manufacturing industry. World Rev Intermodal Transp Res 7(3):195-220

Engström G, Sollander K, Hilletofth P, Eriksson D (2018b) Reshoring drivers and barriers in the Swedish manufacturing industry. J Glob Oper Strateg Sourc 11(2):174-201

Fel F, Griette E (2017) Near-reshoring your supplies from China: a good deal for financial motives too. Strateg Dir 33(2):24-16

Ferdows K (1997) Making the most of foreign factories. Harv Bus Rev 75:73-91

Ferdows K (2018) Keeping up with growing complexity of managing global operations. Int J Oper Prod Manag 38(2):390-402

Fillis I (2001) Small firm internationalisation: an investigative survey and future research directions. Manag Decis 39(9):767-783

Fjellstrom D, Fang T, Chimenson D (2019) Explaining reshoring in the context of Asian competitiveness: evidence from a Swedish firm. J Asia Bus Stud 13(2):277-293

Foerstl K, Kirchoff JF, Bals L (2016) Reshoring and insourcing: drivers and future research directions. Int J Phys Distrib Logist Manag 46(5):492-515

Fontana GL, Miranda JA (2017) Design and fashion as determinants of industrial competitiveness: a comparative study of the evolution of the footwear industry. In Motta G, Biagini A (eds) Italy and Spain, in fashion through history, vol. II Ed. Cambridge Scholars Publishing

Foster K (2016) A prediction of US knit apparel demand: making the case for Reshoring manufacturing investment in new technology. J Text Appar Technol Manag 10(2):1-10

Fox S (2015) Moveable factories: how to enable sustainable widespread manufacturing by local people in regions without manufacturing skills and infrastructure. Technol Soc 42:49-60

Fratocchi L (2018) Additive manufacturing technologies as a reshoring enabler: a why, where and how approach. World Rev Intermodal Transp Res 7(3):264-293

Fratocchi L, Costa e Silva, E (2018) Manufacturing back-shoring and direct brand creation in the footwear industry. In: Advances in Manufacturing Technology XXXII: Proceedings of the 16th International Conference on Manufacturing Research, 8:461

Fratocchi L, Di Stefano C (2019a) Does sustainability matter for reshoring strategies? A literature review. J Glob Oper Strateg Sourc 12(3):449-476

Fratocchi L, Di Stefano C (2019b) Manufacturing reshoring in the fashion industry: a literature review. World Rev Intermodal Transp Res 8(4): 338-365

Fratocchi L, Di Mauro C, Barbieri P, Nassimbeni ZA (2014) When manufacturing moves back: concepts and questions. J Purch Supply Manag 20(1):54-59

Fratocchi L, Ancarani A, Barbieri P, Di Mauro C, Nassimbeni G, Sartor M, Vignoli M, Zanoni A (2015) Manufacturing back-reshoring as a nonlinear internationalization process. In Van Tulder R, Verbeke A, Drogendijk R (eds) The future of global organizing, Progress in international business research (PIBR). Emerald pp 367-405

Fratocchi L, Ancarani A, Barbieri P, Di Mauro C, Nassimbeni G, Sartor M, Vignoli M, Zanoni A (2016) Motivations of manufacturing reshoring: an interpretative framework. Int J Phys Distrib Logist Manag 46(2):98-127

Freeman RB, Kleiner MM (2005) The last American shoe manufacturers: decreasing productivity and increasing profits in the shift from piece rates to continuous flow production. Br J Ind Relat 44(2):307-330

Gadde LE, Jonsson P (2019) Future changes in sourcing patterns: 2025 outlook for the Swedish textile industry. J Purch Supply Manag 25(3): 100526 
Gereffi G (2020) What does the COVID-19 pandemic teach us about global value chains? The case of medical supplies. Journal of International Business Policy 3(3):287-301

Gharleghi B, Jahanshahi AA, Thoene T (2020) Locational factors and the reindustrialisation process in the USA; Reshoring from China. Int $\mathrm{J}$ Bus Glob 24(2):275-292

Gómez N, López LA, Tobarra MA (2006) Pautas de deslocalización de la industria española en el entorno europeo (1995-2000): la competencia de los países de bajos salarios. Boletín Económico de Información Comercial Española 2884:25-42

Grandinetti R, Tabacco R (2015) A return to spatial proximity: combining global suppliers with local subcontractors. Int J Glob Small Bus 7(2):139-161

Grappi S, Romani S, Bagozzi RP (2015) Consumer stakeholder responses to reshoring strategies. J Acad Mark Sci 43(4):453-471

Grappi S, Romani S, Bagozzi RP (2018) Reshoring from a demand-side perspective: consumer reshoring sentiment and its market effects. J World Bus 53(2):194-208

Grappi S, Romani S, Bagozzi RP (2019) The effects of reshoring decisions on employees. Pers Rev 49(6):1254-1268

Grappi S, Romani S, Bagozzi RP (2020) Consumer reshoring sentiment and animosity: expanding our understanding of market responses to reshoring. Manag Int Rev 60(1):69-95

Gray JV, Skowronski K, Esenduran G, Johnny Rungtusanatham M (2013) The reshoring phenomenon: what supply chain academics ought to know and should do. J Supply Chain Manag 49(2):27-33

Gray JV, Esenduran G, Rungtusanatham MJ, Skowronski K (2017) Why in the world did they reshore? Examining small to medium-sized manufacturer decisions. J Oper Manag 49-51:37-51

Gurvich VJ, Hussain AS (2020) In and beyond COVID-19: US academic pharmaceutical science and engineering community must engage to meet critical National Needs. AAPS PharmSciTech 21(5):153

Gutiérrez Ó (2020) Sourcing flexibility with uncertain costs. J Oper Res Soc:1-13. https://doi.org/10.1080/01605682.2020.1730251

Gylling M, Heikkilä J, Jussila K, Saarinen M (2015) Making decisions on offshore outsourcing and backshoring: a case study in the bicycle industry. Int J Prod Econ 162:92-100

Hartman PL, Ogden JA, Wirthlin JR, Hazen BT (2017) Nearshoring, reshoring, and insourcing: moving beyond the total cost of ownership conversation. Bus Horiz 60(3):363-373

Hasan R (2018) Reshoring of US apparel manufacturing: lesson from an innovative North Carolina based manufacturing company. J Text Appar Technol Manag 10(4)

Heikkilä J, Martinsuo M, Nenonen S (2018a) Backshoring of production in the context of a small and open Nordic economy. J Manuf Technol Manag 29(4):658-675

Heikkilä J, Nenonen S, Olhager J, Stentoft J (2018b) Manufacturing relocation abroad and back : empirical evidence from the Nordic countries. World Rev Intermodal Transp Res 7(3):221-240

Hilletofth P, Eriksson D, Tate W, Kinkel S (2019a) Right-shoring: making resilient offshoring and reshoring decisions. J Purch Supply Manag 25(3):100540

Hilletofth P, Sequeira M, Adlemo A (2019b) Three novel fuzzy logic concepts applied to reshoring decision-making. Expert Syst Appl 126:133-143

Hilmola OP, Tolli A, Panova Y (2019) Global corporations and smaller actors in textile business: European perspective. Econ Reg 15(1): 216-230

Huang YS, Chen D (2016) A reversal theory in internationalization: case of Korean jewelry inside China. Chinese Manag Stud 10(1):82-101

Huq F, Pawar KS, Rogers H (2016) Supply chain configuration conundrum: how does the pharmaceutical industry mitigate disturbance factors? Prod Plan Control 27(14):1206-1220

Hutzschenreuter T, Lewin AY, Dresel S (2011) Governance modes for offshoring activities: a comparison of US and German firms. Int Bus Rev 20(3):291-313
Johanson J, Vahlne J-E (1977) The internationalization process of the firm-a model of knowledge development and increasing foreign market commitments. J Int Bus Stud 8(1):23-32

Johanson J, Vahlne J-E (1990) The mechanism of internationalisation. Int Mark Rev 7(4):11-23

Johansson M, Olhager J (2018a) Manufacturing relocation through offshoring and backshoring: the case of Sweden. J Manuf Technol Manag 29(4):637-657

Johansson M, Olhager J (2018b) Comparing offshoring and backshoring: the role of manufacturing site location factors and their impact on post-relocation performance. Int J Prod Econ 205:37-46

Johansson M, Olhager J, Heikkilä J, Stentoft J (2019) Offshoring versus backshoring: empirically derived bundles of relocation drivers, and their relationship with benefits. J Purch Supply Manag 25(3): 100509

Johnson W (2012) Is Nearshoring right for your product? As China matures, a host of factors could rebalance the geographical supply chain. Printed Circuit Design \& Fab

Joubioux C, Vanpoucke E (2016) Towards right-shoring: a framework for off-and re-shoring decision making. Oper Manag Res 9(3):117132

Jung SH (2020) Offshore versus onshore sourcing: quick response, random yield, and competition. Prod Oper Manag 29(3):750-766

Kamann DJ, Van Nieulande V (2010) A four-filter method for outsourcing to low-cost countries. J Supply Chain Manag 46(2): 64-79

Kandil N, Battaia O, Hammami R (2020) Globalisation vs. Slowbalisation: a literature review of analytical models for sourcing decisions in supply chain management. Annu Rev Control 49:277287

Kinkel S (2012) Trends in production relocation and backshoring activities: changing patterns in the course of the global economic crisis. Int J Oper Prod Manag 32(6):696-720

Kinkel S (2014) Future and impact of backshoring - some conclusions from 15 years of research on German practices. J Purch Supply Manag 20(1):63-65

Kinkel S, Maloca S (2009) Drivers and antecedents of manufacturing offshoring and backshoring-a German perspective. J Purch Supply Manag 15(3):154-165

Kinkel S, Lay G, Maloca S (2007) Development, motives and employment effects of manufacturing offshoring of German SMEs. Int J Entrepreneurship Small Bus 4(3):256-276

Kurata H, Nomura R, Suga N (2020) Vertical specialization in northsouth trade: industrial relocation, wage and welfare. Rev Int Econ 28(1):119-137

Kvedaravičienė G (2008) Development of nearshoring in global outsourcing market. Econ Manag:125-126

Lampón JF, González-Benito J (2019) Backshoring and improved key manufacturing resources in firms' home location. Int J Prod Res 58: 6268-6282. https://doi.org/10.1080/00207543.2019.1676479

Lavissière A, Mandják T, Fedi L (2016) The key role of infrastructure in backshoring operations: the case of free zones. Supply Chain Forum 17(3):143-155

Leisner P, Nielsen LP (2019) Offshoring and backshoring of surface finishing from the perspective of the Nordic countries. Trans IMF 97(2):54-56

Lowder S (1999) Globalisation of the footwear industry. A simple case of labour? Tijdschrift voor Ecnomische en Sociale Geografie 90(1): $47-60$

Lund HB, Steen M (2020) Make at home or abroad? Manufacturing reshoring through a GPN lens: a Norwegian case study. Geoforum 113:154-164

Luthra S, Mangla SK, Yadav G (2019) An analysis of causal relationships among challenges impeding redistributed manufacturing in emerging economies. J Clean Prod 225:949-962 
Marin D (2018) Global value chains, the rise of the robots and human capital. Wirtschaftsdienst 98(2276):46-49

Martínez-Mora C, Merino F (2014) Offshoring in the Spanish footwear industry: a return journey? J Purch Supply Manag 20(4):225-237

Martínez-Mora C, Merino F (2020) Consequences of sustainable innovations on the reshoring drivers' framework. J Manuf Technol Manag 31:1373-1390. https://doi.org/10.1108/JMTM-12-2019-0426

Mazzola E, Bruccoleri M, Perrone G (2019) The curvilinear effect of manufacturing outsourcing and captive-offshoring on firms' innovation: the role of temporal endurance. Int J Prod Econ 211:197-210

Młody M (2016) Backshoring in light of the concepts of divestment and De-internationalization: similarities and differences. Entrepreneurial Bus Econ Rev 4(3):167-180

Mohiuddin M, Rashid MM, Al Azad MS, Su Z (2019) Back-shoring or re-shoring: determinants of manufacturing offshoring from emerging to least developing countries (LDCs). Int J Logist Res Appl 22(1):78-97

Moore ME, Rothenberg L, Moser H (2018) Contingency factors and reshoring drivers in the textile and apparel industry. J Manuf Technol Manag 29(6):1025-1041

Moradlou H, Backhouse CJ (2016) A review of manufacturing re-shoring in the context of customer-focused postponement strategies. Proc Inst Mech Eng B J Eng Manuf 230(9):1561-1571

Moradlou H, Tate W (2018) Reshoring and additive manufacturing. World Rev Intermodal Transp Res 7(3):241-263

Moradlou H, Backhouse C, Ranganathan R (2017) Responsiveness, the primary reason behind re-shoring manufacturing activities to the UK. Int J Phys Distrib Logist Manag 47(2-3):222-236

Moretto A, Patrucco AS, Harland CM (2020) The dynamics of reshoring decisions and the role of purchasing. Int J Prod Res 58(19):59295944

Mugurusi G, de Boer L (2014) Conceptualising the production offshoring organisation using the viable systems model (VSM). Strategic Outsourcing: An International Journal 7(3):275-298

Navrotskaia NA, Kovaleva EA, Zenkina EV, Bogacheva TV, Bondarchuk NV (2018) Technological cooperation trends under conditions of the modern world economy. Int J Eng Technol 7(3.15):288-292

Nujen BB, Halse LL (2017) Global shift-back's: a strategy for reviving manufacturing competences. In Torben Pedersen, Timothy M. Devinney, Laszlo Tihanyi, Arnaldo Camuffo (ed.) Breaking up the global value Chain (advances in international management, volume 30) Emerald publishing limited, pp. 245-267

Nujen BB, HalseLL DR, Gammelsæter H (2018) Managing reversed (global) outsourcing-the role of knowledge, technology and time. Manuf Technol Manag 29(4):676-698

Nujen BB, Mwesiumo DE, Solli-Sæther H, Slyngstad AB, Halse LL (2019) Backshoring readiness. J Glob Oper Strateg Sourc 12(1): $172-195$

Ohmae K (1985) Triad power: the coming shape of global competition. The Free Press, New York, USA

Orzes G, Sarkis J (2019) Reshoring and environmental sustainability: an unexplored relationship? Resour Conserv Recycl 141:481-482

Oshri I, Sidhu JS, Kotlarsky J (2019) East, west, would home really be best? On dissatisfaction with offshore-outsourcing and firms' inclination to backsource. J Bus Res 103:644-653

Pal R, Harper S, Vellesalu A (2018) Competitive manufacturing for reshoring textile and clothing supply chains to high-cost environment. Int J Logist Manag 29(4):1147-1170

Piatanesi B, Arauzo-Carod JM (2019) Backshoring and nearshoring: an overview. Growth Chang 50:806-823

Presley A, Meade L, Sarkis J (2016) A strategic sourcing evaluation methodology for reshoring decisions. Supply Chain Forum 17(3): 156-169
Radi D, Lamantia F, Bischi GI (2019) Offshoring, reshoring, unemployment, and wage dynamics in a two-country evolutionary model. Macroecon Dyn:1-28

Rasel S, Abdulhak I, Kalfadellis P, Heyden ML (2020) Coming home and (not) moving in? Examining reshoring firms' subnational location choices in the United States. Reg Stud 54(5):704-718

Rashid A, Barnes L (2017) Country of origin: Reshoring implication in the context of the UK fashion industry. Reshoring of Manufacturing: $183-201$

Razvadovskaya YV, Shevchenko IK (2015) Dynamics of metallurgic production in emerging countries. Asian Soc Sci 11(19):178

Robinson PK, Hsieh L (2016) Reshoring: a strategic renewal of luxury clothing supply chains. Oper Manag Res 9(3-4):89-101

Saki Z (2016) Disruptive innovations in manufacturing-an alternative for re-shoring strategy. J Text Appar Technol Manag 10(2):1-7

Sansone C, Hilletofth P, Eriksson D (2020) Critical operations capabilities for competitive manufacturing in a high-cost environment: a multiple case study. Operations and Supply Chain Management 13(1):94-107

Sardar S, Lee YH (2015) Analysis of product complexity considering disruption cost in fast fashion supply chain. Math Probl Eng 670831

Sardar S, Lee YH, Memon MS (2016) A sustainable outsourcing strategy regarding cost, capacity flexibility, and risk in a textile supply chain. Sustain Sci 8(3):234

Sayem A, Feldmann A, Ortega-Mier M (2019) Investigating the influence of network-manufacturing capabilities to the phenomenon of reshoring: an insight from three case studies. BRQ Bus Res Q 22(1): 68-82

Schmidt AST, Touray E, Hansen ZNL (2017) A framework for international location decisions for manufacturing firms. Prod Eng 11(6): $703-713$

Scott AJ (2006) The changing global geography of low-technology, labor-intensive industry: clothing, footwear, and furniture. World Dev 34(9):1517-1536

Shamis GS, Green MC, SorensenSM KDL (2005) Outsourcing, offshoring, nearshoring: what to do? J Account 199(6):57-61

Sharfman MP, Wolf G, Chase RB, Tansik DA (1988) Antecedents of organizational slack. Acad Manag Rev 13(4):601-614

Sirilertsuwan P, Ekwall D, Hjelmgren D (2018) Proximity manufacturing for enhancing clothing supply chain sustainability. Int J Logist Manag 29(4):1346-1378

Sirilertsuwan P, Hjelmgren D, Ekwall D (2019) Exploring current enablers and barriers for sustainable proximity manufacturing. J Fash Mark Manag 23(4):551-571. https://doi.org/10.1108/JFMM-092018-0114

Slepniov D, Brazinskas S, Wæhrens BV (2013) Nearshoring practices: an exploratory study of Scandinavian manufacturers and Lithuanian vendor firms. Balt J Manag 8(1):5-26

Srai JS, Ané C (2016) Institutional and strategic operations perspectives on manufacturing reshoring. Int J Prod Res 54(23):7193-7211

Stentoft J, Mikkelsen OS, Jensen JK (2016a) Flexicurity and relocation of manufacturing. Oper Manag Res 9(3-4):133-144

Stentoft J, Mikkelsen OS, Jensen JK (2016b) Offshoring and backshoring manufacturing from a supply chain innovation perspective. Supply Chain Forum 17(4):190-204

Stentoft J, Olhager J, Heikkilä J, Thoms L (2016c) Manufacturing backshoring: a systematic literature review. Oper Manag Res 9(34):53-61

Stentoft J, Mikkelsen OS, Jensen JK, Rajkumar C (2018) Performance outcomes of offshoring, backshoring and staying at home manufacturing. Int J Prod Econ 199:199-208

Strange R (2020) The 2020 Covid-19 pandemic and global value chains. Journal of Industrial and Business Economics 47(3):455-465

Sutherland JW, Richter JS, Hutchins MJ, Dornfeld D, Dzombak R, Mangold J, Robinson S, Hauschild MZ, Bonou A, Schönsleben P, 
Friemann F (2016) The role of manufacturing in affecting the social dimension of sustainability. CIRP Ann Manuf Technol 65(2):689-712

Talamo G, Sabatino M (2018) Reshoring in Italy: a recent analysis. Contemp Econ 12(4):381-399

Tate WL (2014) Offshoring and reshoring: US insights and research challenges. J Purch Supply Manag 20(1):66-68

Tate WL, Bals L (2017) Outsourcing/offshoring insights: going beyond reshoring to rightshoring. Int J Phys Distrib Logist Manag 47(2-3): $106-113$

Tate WL, Ellram LM, Schoenherr T, Petersen KJ (2014) Global competitive conditions driving the manufacturing location decision. Bus Horiz 57(3):381-390

Thakur-Wernz P (2019) A typology of backsourcing: short-run total costs and internal capabilities for re-internalization. J Glob Oper Strateg Sourc 12(1):42-61

Theyel G, Hofmann K, Gregory M (2018) Understanding manufacturing location decision making: rationales for retaining, offshoring, reshoring, and hybrid approaches. Econ Dev Q 32(4):300-312

Tortajada E, Fernández I, Ybarra J (2005) Evolución de la industria españoola del calzado: factores relevantes en las úlltimas décadas. Econ Ind Democr 355:211-227

UK Government (2014) World economic forum 2014: speech by David Cameron. https://www.gov.uk/government/speeches/worldeconomic-forum-davos-2014-speech-by-davidcameron\%2D\%2D2

Uluskan M, Joines JA, Godfrey AB (2016) Comprehensive insight into supplier quality and the impact of quality strategies of suppliers on outsourcing decisions. Supply Chain Manag 21(1):92-102

Uluskan M, Godfrey AB, Joines JA (2017) Impact of competitive strategy and ... relocation) decisions. J Text Inst 108(8):1308-1318

UNCTAD (2020) World investment report 2020. International Production Beyond the Pandemic. United Nations Conference on Trade and Development. https:/unctad.org/en/PublicationsLibrary/ wir2020_en.pdf

Vanchan V, Mulhall R, Bryson J (2018) Repatriation or reshoring of manufacturing to the US and UK: dynamics and global production networks or from here to there and back again. Growth Chang 49(1): $97-121$

Verdu AJ, Gómez-Gras JM, Martínez-Mateo J (2012) Value creation through production offshore-inshore strategies in a footwear industry cluster: a coevolutionary perspective. Int Bus Rev 21(3): $342-356$

Vissak T (2010) Nonlinear internationalization: a neglected topic in international business research. In: Devinney, T., Pedersen, T. and Tihanyi, L. (Eds.) The past, present and future of international business and management. Emerald, Bingley, pp. 559-583

Wan L, Orzes G, Sartor M, Di Mauro C, Nassimbeni G (2019a) Entry modes in reshoring strategies: an empirical analysis. J Purch Supply Manag 25(3): 100522

Wan L, Orzes G, Sartor M, Nassimbeni G (2019b) Reshoring: does home country matter? J Purch Supply Manag 25(4):100551

Wiesmann B, Snoei JR, Hilletofth P, Eriksson D (2017) Drivers and barriers to reshoring: a literature review on offshoring in reverse. Eur Bus Rev 29(1):15-42

Wu X, Zhang F (2014) Home or overseas? An analysis of sourcing strategies under competition. Manag Sci 60(5):1223-1240

Wu P, Jin Y, Shi Y, Shyu H (2017) The impact of carbon emission costs on manufacturers' production and location decision. Int J Prod Econ 193:193-206

Yegul MF, Erenay FS, Striepe S, Yavuz M (2017) Improving configuration of complex production lines via simulation-based optimization. Comput Ind Eng 109:295-312

$\mathrm{Yu}$ UJ, Kim JH (2018) Financial productivity issues of offshore and "made-in-USA" through reshoring. J Fash Mark Manag 22(3): 317-334

Zhai W (2014) Competing back for foreign direct investment. Econ Model39:146-150

Zhai W, Sun S, Zhang G (2016) Reshoring of American manufacturing companies from China. Oper Manag Res 9(3-4):62-74

Zhang A, Huang GQ (2012) Impacts of business environment changes on global manufacturing outsourcing in China. J Purch Supply Manag 17(2):138-151

Zhao L, Huchzermeier A (2017) Integrated operational and financial hedging with capacity reshoring. Eur J Oper Res 260(2):557-570

Publisher's note Springer Nature remains neutral with regard to jurisdictional claims in published maps and institutional affiliations. 